\title{
Potentiality of BBF and Soil Amendments in Degraded Purnavalley Soils Reclamation and Soybean Yield
}

\author{
J. Ravinder ${ }^{1}$, Tupaki Lokya ${ }^{1}$, N.M. Konde ${ }^{1}$ and Princy Thakur $^{2}$ \\ ${ }^{1}$ Department of Soil Science and Agricultural Chemistry, Post Graduate Institute, Dr. Panjabrao \\ Deshmukh Krishi Vidyapeeth, Akola, Maharashtra, 444104, India \\ ${ }^{2}$ Department of Soil Science and Agricultural Chemistry, UBKV, Pundibari, Cooch Behar, \\ West Bengal, 736165, India \\ *Corresponding author
}

\section{A B S T R A C T}

\begin{tabular}{|l|}
\hline Ke y w o r d s \\
Antibiotic, \\
Anti-fungal, \\
Bioactive \\
compounds, \\
Bacterial \\
endophytes, \\
Natural products. \\
\hline Article Info \\
\hline Accepted: \\
29 May 2017 \\
Available Online: \\
10 June 2017
\end{tabular}

The present investigation was carried out to study the Effect of BBF and soil amendments on soluble cations and anions, available NPK and soybean yield in salt affected soils of Purna valley in Vidarbha region of Maharashtra. The treatments comprised of only BBF, BBF + FYM @ $5 \mathrm{t} \mathrm{ha}^{-1}$, $\mathrm{BBF}+$ gypsum @2.5 $\mathrm{t} \mathrm{ha}^{-1}$ and BBF + FYM@5 $\mathrm{t} \mathrm{ha}^{-1}+$ gypsum @ $1.25 \mathrm{t} \mathrm{ha}^{-1}$ combinely. Treatments replicated in six farmers' fields one farmer as one replication with randomized block design. In this region shallow saline groundwater table, poor drainage and sub soil Sodicity are the main problems. In this context, $\mathrm{BBF}$ and soil amendments were drawn more attention to ameliorate these degraded soils. Under the study $\mathrm{pHs}$ was influenced slightly under all treatments and higher rate of decrease was noticed in treatment $\mathrm{T}_{4}$ (8.24). By incorporating FYM @ $5 \mathrm{t} \mathrm{ha}^{-1}$ highest ECe was noticed in $\mathrm{T}_{2}\left(0.78\left(\mathrm{dSm}^{-1}\right)\right.$. It was significantly less $\left(0.54 \mathrm{dSm}^{-1}\right)$ in $_{1}$ where only BBF was practiced. Use of FYM and gypsum recorded considerable increase in soluble $\mathrm{Ca}, \mathrm{Mg}$ and $\mathrm{K}$ but decrease in $\mathrm{Na}$. In respect of bicarbonates the significant reduction was observed in treatment $\mathrm{T}_{3}$, $\mathrm{BBF}+$ gypsum@2.5tha ${ }^{-1}$. Concentration of chlorides and sulphates also reduced in $\mathrm{T}_{4}\left(1.06\left(\mathrm{me} \mathrm{L}^{-1}\right)\right.$ due to combined application of FYM @ $5 \mathrm{t} \mathrm{ha}^{-1}$ and gypsum @ $1.25 \mathrm{t} \mathrm{ha}^{-1}$. $\mathrm{InT}_{3}$ also observed remarkable reduction over $T_{1}$. However, the combined practice of BBF with organic and inorganic amendments reportedly profitable in amelioration, nutrient uptake and also a great advantage in straw and grain yield of soybean for salt affected soils of purna valley in vidarbha.

\section{Introduction}

The Purna valley is the unique tract of Vertisols in Vidarbha region (M.S.) of India having combination of three fold problems, the native salinity, poor drainability and poor quality of ground water. The unique features of the salt affected soils of Purna valley is that though the salinity and sodicity is widely reported in this tract the presence of salt on surface is hardly seen. The Purna valley of Vidarbha region is an east-west elongated basin with slight covering to the south occupying the part of Amravati, Akola and
Buldhana districts of Vidarbha and extends from $20^{\circ} 45^{\prime}$ to $21^{\circ} 15^{\prime} \mathrm{N}$ latitude and $75^{\circ} 25^{\prime}$ to $77^{\circ} 45^{\prime} \mathrm{E}$ longitude with east-west length of $100-150 \mathrm{~km}$ having width of about 10 to 60 $\mathrm{km}$ covering an area of about 4.69 lakh hectares distributed in Amravati (1738 sq. $\mathrm{km}$ ), Akola (1939 sq. km) and Buldhana (1015 sq. km).(Anonymous, 2010). These soils of are developed on basaltic alluvium under arid and semi-arid conditions have clay mineralogy, high swell-shrink potential, slow permeability with very low hydraulic 
conductivity and poor drainage conditions. Taxonomically these salt affected soils are classified as Sodic Haplusterts and Sodic Calciusterts (Padole et al., 1998).

The soil solution of a salty soil mainly contains cations like $\mathrm{Na}^{+}, \mathrm{Ca}^{2+}, \mathrm{Mg}^{2+}$ and $\mathrm{K}^{+}$ and anions like $\mathrm{Cl}^{-}, \mathrm{SO}_{4}{ }^{-2}, \mathrm{HCO}_{3}{ }^{-}, \mathrm{CO}_{3}{ }^{-} \mathrm{NO}_{3}{ }^{-}$. The dominant cation in salty soils is $\mathrm{Na}+$, which usually exceeds the concentration of $\mathrm{Ca}^{2+}$ and $\mathrm{Mg}^{2+}$. The predominant anions are $\mathrm{Cl}^{-}$and $\mathrm{SO}_{4}{ }^{-2}$ and some $\mathrm{HCO}_{3}{ }^{-}$at normal $\mathrm{pH}$ values of 6 to 8 , while $\mathrm{CO}_{3}{ }^{-2}$ is found at $\mathrm{pH}$ above 8.5. The solid phase (clay particles, humus) of the soil has a negative charge and it adsorbs positively charged cations from the soil solution in order of adsorption preference: $\mathrm{NH}_{4}+>\mathrm{Ca}^{2+}>\mathrm{Mg}^{2+}>\mathrm{H}^{+}>\mathrm{K}^{+}>$ $\mathrm{Na}^{+}$. These cations are mutually replaceable or exchangeable. Soil colloids containing a high portion of $\mathrm{Ca}^{2+}$ and other divalent ions form strong bonds between mineral particles and, consequently a stable structure. Soils rich in $\mathrm{Na}^{+}$have loose bonds and a weak soil structure.

Soybean (Glycine max. L.) is one of the important oil seed as well as leguminous crop. It is originated in Eastern Asia/China. It is second largest oil seed crop in India after groundnut. Soybean as a miracle "Golden bean" of the $21^{\text {st }}$ century mainly due to its high content protein - 40\%, oil - 20\%, carbohydrates $-30 \%$, fibre $-0.5 \%$, lecithin $0.5 \%$, Vitamin C - 10\%, Calcium - 27\%, Iron $87 \%$, Vitamin B1 and B6 - 20\%, Magnesium $-70 \%$ and saponins - 4\%, and it is now making headway in Indian Agriculture. Soybean has special qualities such as ease in cultivation, less fertilizer and labour requirement. It fixes nitrogen and leaves about $25 \%$ for succeeding crop. Soybean is cultivating in the world over an area of 71.85 million hectares with a production of 154.32 million tonnes. In India grown on an area of about 6 million hectare with production for
Kharif 2014 is 104.36 Lakh MT as compared to 94.768 Lakh MT during Kharif 2013 indicating an increase of $10.12 \%$ over previous year.

In Maharashtra the area under Soybean Cultivation during Kharif 2014 was 38.704 Lakh hectare as compared to 38.00 Lac hectares during Kharif 2013. The yield was $808 \mathrm{Kg} \mathrm{ha}^{-1}$ resulting into a production of 30.721 Lac MT during Kharif 2014. In Vidarbha the area under soybean during Kharif 2014 was 20.93 Lakh hectares as compared to $19.31 \mathrm{Lac}$ hectares while in 2013 it was less Rochester et al., (2001).

\section{Materials and Methods}

The experiment was conducted on six farmer's field with soybean crop in Ramagarh located at Dharyapur tehsil of Amravati district of Vidarbha region of Maharashtra during kharif, $2014-15$. The design of experiment was randomized block design (RBD), replicated six times, where each farmer was treated as one replication with four treatments comprised of only BBF, BBF +FYM@5 tha ${ }^{-1}, \mathrm{BBF}+$ gypsum @2.5 tha 1 and BBF + FYM @ 5 t ha ${ }^{-1}+$ gypsum @ $1.25 \mathrm{t} \mathrm{ha}^{-1}$ combined. Characteristics of the soils are comprised of clayey montmorillonitic, deep with soil order Vertisols. The initial physical and chemical properties of the experimental soils were analyzed and presented in table 1. Soil samples were collected before sowing and after harvest of soybean and analyzed for the soil for soluble cations and anions. The saturated paste was prepared and the extract was obtained. The method described by Richards (1954) was followed for the saturation extract preparation. These soil samples were analysed for $\mathrm{pHs,} \mathrm{electrical}$ conductivity (ECe) and cations and anions as per the methods outlined by Richards (1954).Available Nitrogen was determined by 
alkaline permanganate method as described by Subbiah and Asija (1956). Available phosphorus determined by Olsen's method as described by Watanabe and Olsen using 0.5 $\mathrm{M}$ sodium bicarbonate $\mathrm{pH}$ (8.5) as an extractant. Darco-G-60 soluble phosphorus was used to absorb the dispersed organic matter and make the filtrate colourless for further colorimetric analysis. (Watanabe and Olsen, 1965).Available potassium was determined by the flame photometer using neutral $\mathrm{N}$ ammonium acetate $(\mathrm{pH} 7.0)$ as an extractant as described by Hanway and Heidel (1952).Similarly Seed and straw yields were recorded during the field experimentation. The data on different parameters were tabulated and analyzed statistically by the methods described by Panse and Sukhatme (1971).

\section{Results and Discussion}

The obtained by analysing saturated paste extract for different parameters are shown here under.

\section{pHs}

pHs was decreased slightly under all treatments and higher rate of decrease was noticed in treatment $\mathrm{T}_{4}$ (8.24) in which treatment organic and inorganic amendments are used combinedly. The reduction in $\mathrm{pHs}$ under organic amendments might be due to decomposition of organic amendments which produce organic acids there by solubilizing native calcium carbonate facilitating faster reclamation. Similar findings were also reported by Choudhary et al., (2011). In $\mathrm{T}_{3}$ also noticeable reduction was took place where gypsum as amendment used. Decrease in $\mathrm{pHs}$ of Sodic Haplusterts due to incorporation of gypsum could possibly be due to suppression of SAR/ESP of sodic Haplusterts. Similar findings were noticed by More et al., (1987) in respect of sodic
Vertisols of Marathwada (Maharashtra) region. The descending order of $\mathrm{pHs}$ with increasing levels of gypsum applied in salt affected Vertisols was recorded by Tiwariet al., (1993). A significant positive correlation of $\mathrm{pHs}$ with gypsum requirement was stated by Manish and Chauhan (1983).

\section{ECe}

The electrical conductivity (EC) of a soil extract is an indirect expression of the total salt concentration in the soil, without reference to the nature and composition of the salts. The EC is expressed in $\mathrm{dS} / \mathrm{m}$ (or $\mathrm{mmhos} / \mathrm{cm}$ in older literature); it is measured at a standard temperature of $25{ }^{\circ} \mathrm{C}$ to avoid the influence of temperature.

The electrical conductivity of saturation paste extract was influenced slightly under all the treatments however, the increase in ECe was well within permissible limit of salinity hazards. The highest significant decrease in $\mathrm{ECe}$ was found under BBF+ FYM in $\mathrm{T}_{2}(0.78$ dS $\mathrm{m}^{-1}$ ) followed by BBF+ gypsum Incorporation in $\mathrm{T}_{3}\left(0.64 \mathrm{dS} \mathrm{m}^{-1}\right)$ and $\mathrm{BBF}+$ gypsum + FYM incorporation in $\mathrm{T}_{4}(0.58 \mathrm{dS}$ $\mathrm{m}^{-1}$ ) over control $\left(0.54 \mathrm{dS} \mathrm{m}^{-1}\right)$ (Table 2$)$.

The slight increase in ECe due to application of gypsum and organic amendments were also reported by Choudhary et al., (2011) and Kaur (2008). Reclamation of alkali soils requires assured water supplies after incorporation of organic and chemical amendments; the raised and sunken bed system has been suggested for improving drainage and water storage under rainfed condition which may result into repression in ECe of sodic Vertisols Gupta et al., (1988). In this investigation, furrow acts as sunken bed, whereas raised portion between two furrows acts as raised beds. Bharambe et al., (2001). Stated that use of chemical and organic amendments for reclamation of sodic soils 
was not found detrimental as per as electrical conductivity is concerned.

\section{Soluble cations}

Based on the data obtained in respect of calcium and magnesium, during examination, it was noticed that the highest value of soluble calcium (5.70me $\mathrm{L}^{-1}$ ) and magnesium (5.25 me $\mathrm{L}^{-1}$ ) were found in treatment $\mathrm{T}_{3}$ in which gypsum @ $2.5 \mathrm{t} \mathrm{ha}{ }^{-1}$ was incorporated. Similarly more or less closer values to the treatment $\mathrm{T}_{3}$ were also noted in the treatment $\mathrm{T}_{4}$, where gypsum @ $2.5 \mathrm{t} \mathrm{ha}^{-1}$ along with FYM@ $5 \mathrm{tha}^{-1}$. This may be due to application of organic amendments which released remarkable amounts of calcium to soil solution and which was located on exchangeable sites or was removed from the soil during reclamation process. The results are in conformity with the results of Dubey and Mondal (1994), while studying the effect of gypsum on rice and wheat in sodic soil observed an increase in the exchangeable $\mathrm{Ca}^{++}, \mathrm{Mg}^{++}$with gypsum incorporation. In the leachate collected from amended soil, the calcium content was enhanced with increasing levels of applied gypsum (Shivakant and Rajkumar, 1992) (Table 3).

Table.1 Native status of the soil (2013-14)

\begin{tabular}{|c|c|c|c|c|c|c|c|c|}
\hline S.NO & \multicolumn{2}{|c|}{ Parameter } & REP I & REP II & REP III & REP IV & REP V & REP VI \\
\hline 1 & \multicolumn{2}{|c|}{ B D $\left(\mathrm{Mgm}^{-3}\right)$} & 1.88 & 1.85 & 1.84 & 1.80 & 1.81 & 1.87 \\
\hline 2 & \multicolumn{2}{|c|}{$\mathrm{HC}\left(\mathrm{cmhr}^{-1}\right)$} & 0.49 & 0.53 & 0.48 & 0.51 & 0.47 & 0.49 \\
\hline 3 & \multicolumn{2}{|c|}{ MWD (mm) } & 0.58 & 0.57 & 0.63 & 0.65 & 0.63 & 0.59 \\
\hline 4 & \multicolumn{2}{|c|}{$\mathrm{pH}(1: 2)$} & 8.50 & 8.67 & 8.64 & 8.51 & 8.57 & 8.68 \\
\hline 5 & \multicolumn{2}{|c|}{$\operatorname{Ec}\left(\mathrm{dSm}^{-1}\right)$} & 0.34 & 0.46 & 0.53 & 0.39 & 0.38 & 0.41 \\
\hline 6 & \multicolumn{2}{|c|}{$\mathrm{OC}\left(\mathrm{gkg}^{-1}\right)$} & 5.58 & 5.55 & 5.61 & 5.49 & 5.55 & 5.60 \\
\hline 7 & \multicolumn{2}{|c|}{$\mathrm{CaCo}_{3}(\%)$} & 9.87 & 9.84 & 9.77 & 9.82 & 9.80 & 9.86 \\
\hline 8 & Exch.Ca & \multirow{5}{*}{$\begin{array}{c}(\mathrm{cmol} \\
\left(\mathrm{p}^{+}\right) \\
\left.\mathrm{kg}^{-1}\right)\end{array}$} & 29.66 & 29.48 & 29.69 & 29.60 & 29.73 & 28.88 \\
\hline 9 & Exch.Mg & & 16.13 & 15.33 & 16.27 & 16.08 & 16.05 & 15.21 \\
\hline 10 & Exch.Na & & 2.86 & 2.91 & 2.77 & 2.85 & 2.78 & 2.94 \\
\hline 11 & Exch.K & & 0.95 & 0.88 & 0.98 & 0.87 & 0.85 & 0.91 \\
\hline 12 & CEC & & 49.98 & 49.87 & 48.98 & 50.04 & 49.84 & 47.99 \\
\hline 13 & \multicolumn{2}{|c|}{ pHs (1:2) } & 8.46 & 8.54 & 8.58 & 8.66 & 8.43 & 8.54 \\
\hline 14 & \multicolumn{2}{|c|}{$\mathrm{ECe}\left(\mathrm{dSm}^{-1}\right)$} & 0.86 & 0.88 & 0.79 & 0.76 & 0.91 & 0.77 \\
\hline 15 & \multicolumn{2}{|c|}{$\mathrm{Sol} \mathrm{Ca}\left(\mathrm{me} \mathrm{L}^{-1}\right)$} & 3.26 & 3.34 & 3.16 & 3.20 & 3.19 & 3.28 \\
\hline 16 & \multicolumn{2}{|c|}{$\operatorname{SolMg}\left(\mathrm{me} \mathrm{L}^{-1}\right)$} & 2.58 & 2.64 & 2.43 & 2.33 & 2.65 & 2.47 \\
\hline 17 & \multicolumn{2}{|c|}{$\operatorname{SolNa}\left(\mathrm{me} \mathrm{L}^{-1}\right)$} & 7.23 & 7.36 & 7.18 & 7.22 & 7.14 & 7.13 \\
\hline 18 & \multicolumn{2}{|c|}{ Sol K(me L $\left.{ }^{-1}\right)$} & 0.64 & 0.58 & 0.60 & 0.61 & 0.55 & 0.52 \\
\hline 19 & \multicolumn{2}{|c|}{$\mathrm{HCo}_{3}{ }^{-}\left(\mathrm{me} \mathrm{L}^{-1}\right)$} & 7.32 & 7.41 & 7.30 & 7.29 & 7.26 & 7.22 \\
\hline 20 & \multicolumn{2}{|c|}{$\mathrm{Cl}^{-}\left(\mathrm{me} \mathrm{L}^{-1}\right)$} & 1.44 & 1.53 & 1.26 & 1.18 & 1.41 & 1.43 \\
\hline 21 & \multicolumn{2}{|c|}{$\mathrm{So}_{4}{ }^{-2}\left(\mathrm{me} \mathrm{L}^{-1}\right)$} & 4.61 & 4.54 & 4.69 & 4.53 & 4.58 & 4.47 \\
\hline 22 & \multicolumn{2}{|c|}{ Avail. N (Kg/ha) } & 176.65 & 168.94 & 178.09 & 175.55 & 173.42 & 177.88 \\
\hline 23 & \multicolumn{2}{|c|}{ Avail. $\mathrm{P}(\mathrm{kg} / \mathrm{ha})$} & 18.98 & 18.86 & 18.91 & 18.95 & 18.90 & 18.99 \\
\hline 24 & \multicolumn{2}{|c|}{ Avail. K (kg/ha) } & 324.65 & 323.38 & 325.21 & 329.41 & 324.77 & 325.36 \\
\hline
\end{tabular}


Table.2 Effect of BBF and soil amendments on pHs and ECe $\left(\mathrm{dSm}^{-1}\right)$

\begin{tabular}{|l|l|l|l|}
\hline Tr.No. & Treatments & pHs & ECe $\left(\mathbf{d S m}^{-1}\right)$ \\
\hline T1 & BBF & 8.39 & 0.54 \\
\hline T2 & BBF+ FYM @ 5 tha & -1 \\
\hline T3 & BBF+ Gypsum @ 2.5 tha & -1 \\
\hline T4 & $\begin{array}{l}\text { BBF+ FYM @ 5 tha } \\
\text { Gypsum @ 1.25 tha }\end{array}$ & 8.27 & 0.78 \\
\hline & SE(m) \pm & 8.24 & 0.54 \\
\hline & CD at 5\% & 0.02 & 0.13 \\
\hline & & 0.06 & 0.38 \\
\hline & & 8.54 & 0.83 \\
\hline
\end{tabular}

Table.3 Effect of BBF and soil amendments on soluble cations

\begin{tabular}{|c|c|c|c|c|c|}
\hline \multirow[t]{2}{*}{ Tr.No. } & \multirow[t]{2}{*}{ Treatments } & $\mathrm{Ca}^{2+}$ & $\mathrm{Mg}^{2+}$ & $\mathrm{Na}^{+}$ & $\mathbf{K}^{+}$ \\
\hline & & \multicolumn{4}{|c|}{$\left(m e L^{-1}\right)$} \\
\hline $\mathrm{T} 1$ & $\mathrm{BBF}$ & 3.98 & 2.67 & & 0.67 \\
\hline $\mathrm{T} 2$ & BBF+FYM@5 tha ${ }^{-1}$ & 4.72 & 3.97 & 6.25 & 0.74 \\
\hline T3 & BBF+Gypsum @ 2.5 tha $^{-1}$ & 5.70 & 5.25 & 5.61 & 0.82 \\
\hline $\mathrm{T} 4$ & $\begin{array}{l}\text { BBF+ FYM @ } 5 \text { tha }^{-1}+\text { Gypsum } \\
@ 1.25 \text { tha }^{-1}\end{array}$ & 5.50 & 4.83 & 5.48 & 0.87 \\
\hline & $\mathrm{SE}(\mathrm{m}) \pm$ & 0.09 & 0.21 & 0.12 & 0.03 \\
\hline & $\mathrm{CD}$ at $5 \%$ & 0.25 & 0.62 & 0.34 & 0.09 \\
\hline & Initial status & $\begin{array}{c}3.24 \\
3.24\end{array}$ & 2.52 & 7.21 & 0.58 \\
\hline
\end{tabular}

Table.4 Effect of BBF and Soil amendments on soluble anions

\begin{tabular}{|l|l|l|l|l|}
\hline Tr.No. & Treatments & $\mathbf{H C o}_{3}^{-}\left(\mathbf{m e ~ L}^{-1}\right)$ & $\mathbf{C l}^{-}\left(\mathbf{m e ~ L}^{-1}\right)$ & $\mathbf{S o}_{4}^{-2}\left(\mathbf{m e ~ L}^{-1}\right)$ \\
\hline T1 & BBF & 7.28 & 1.95 & 4.92 \\
\hline T2 & BBF+ FYM @ 5 tha & -1 & 1.65 & 4.41 \\
\hline T3 & BBF+ Gypsum @ 2.5 tha & -1 \\
\hline T4 & $\begin{array}{l}\text { BBF+ FYM @ 5 tha } \\
\text { Gypsum @ 1.25 tha }\end{array}$ & 5.55 & 1.21 & 3.58 \\
\hline & SE(m) \pm & 3.42 & 1.06 & 3.18 \\
\hline & CD at 5 \% & 0.24 & 0.07 & 0.16 \\
\hline & Initial status & 0.71 & 0.20 & 0.45 \\
\hline & 7.32 & 1.44 & 4.57 \\
\hline
\end{tabular}


Table.5 Effect of BBF and Soil amendments on available nitrogen, phosphorus and potassium

\begin{tabular}{|c|c|c|c|c|}
\hline Tr.No. & Treatments & $\mathbf{N}\left(\mathrm{kgha}^{-1}\right)$ & $\mathbf{P}\left(\right.$ kgha $\left.^{-1}\right)$ & K(kgha $\left.{ }^{-1}\right)$ \\
\hline $\mathrm{T} 1$ & $\mathrm{BBF}$ & 189.57 & 19.28 & 336.08 \\
\hline $\mathrm{T} 2$ & BBF+FYM @ 5 tha $^{-1}$ & 193.31 & 22.49 & 340.53 \\
\hline T3 & BBF+Gypsum @ 2.5 tha $^{-1}$ & 196.32 & 23.32 & 346.12 \\
\hline $\mathrm{T} 4$ & $\begin{array}{l}\text { BBF+FYM @ } 5 \text { tha }^{-1}+ \\
\text { Gypsum @1.25 } \text { tha }^{-1}\end{array}$ & 198.30 & 24.50 & 344.35 \\
\hline & $\mathrm{SE}(\mathrm{m}) \pm$ & 0.69 & 0.22 & 0.87 \\
\hline & $\mathrm{CD}$ at $5 \%$ & 2.03 & 0.67 & 2.56 \\
\hline & Initial status & 175.09 & 18.93 & 325.465 \\
\hline
\end{tabular}

Table.6 Effect of BBF and soil amendments on soybean yield

\begin{tabular}{|l|l|l|l|}
\hline Tr.No. & Treatments & Grain qha $^{-1}$ & Straw qha $^{-1}$ \\
\hline T1 & BBF & 10.33 & 14.55 \\
\hline T2 & BBF+ FYM @ 5 t ha & -1 \\
\hline T3 & BBF+ Gypsum @ 2.5 t ha & 12.05 & 18.47 \\
\hline T4 & $\begin{array}{l}\text { BBF+ FYM @ 5 t ha } \\
\text { Gypsum @ 1.25 t ha }\end{array}$ & 13.70 & 20.20 \\
\hline & SE(m) \pm & 14.03 & 23.10 \\
\hline & CD at 5\% & 0.27 & 0.56 \\
\hline & C.V & 0.78 & 1.62 \\
\hline
\end{tabular}

The soluble sodium values varied from $(5.48$ me $\left.\mathrm{L}^{-1}\right)$ in $\mathrm{T}_{4}$ to $\left(6.68 \mathrm{me} \mathrm{L}^{-1}\right)$ in $\mathrm{T}_{1}$. The significant reduction of sodium was noticed in treatments $\mathrm{T}_{4}$ and $\mathrm{T}_{3}$. Reduction in soluble $\mathrm{Na}$ content in saturation paste extract under gypsum and FYM applied treatments, this might be due to removal of $\mathrm{Na}$ due as reclamation process. These results are in conformity with the findings of Singh et al., (1980). It is obvious to reduce the ionic $\mathrm{Na}$ due to addition of $\mathrm{Ca}$ through amendments, which replaces $\mathrm{Na}$ from the clay complex of surface soil, $\mathrm{Na}$ decreased with increasing levels of applied amendments (Patel and Singh, 1991).

The increase in soluble potassium all treatments except treatment $T_{1}$ The highest value of soluble $\mathrm{K}$ was noticed in treatment $\mathrm{T}_{4}\left(0.87 \mathrm{me} \mathrm{L}^{-1}\right)$ where FYM and gypsum were combined @ $5 \mathrm{t} \mathrm{ha}^{-1}$ and $1.25 \mathrm{t} \mathrm{ha}^{-1}$ respectively. The soluble potassium in $T_{3}$ (0.82 $\mathrm{me}^{-1}$ ) also increased considerably. The increase of $\mathrm{K}$ in organic amendments is due to addition of potassium through biomass. These findings are resembles with the results of Kharche et al., (2010) studied integrated use of gypsum and organic amendments and bio-inoculants for reclamation of sodic swell shrink soils of Mula command area and reported that combined use of gypsum and organic amendments increased soluble $\mathrm{K}$ concentration Similar results were also reported by Murtaza et al., (1999) and Sharma et al., (2001).

\section{Soluble anions}

In respect of bicarbonates the highest significant reduction was observed in $\mathrm{T}_{3}(3.42$ me $\mathrm{L}^{-1}$ ) where was gypsum applied @ $2.5 \mathrm{t}$ ha $^{-1}$ while in treatment $\mathrm{T}_{4}\left(3.63 \mathrm{me} \mathrm{L}^{-1}\right)$ also 
remarkable reduction was noted in which farm yard manure and gypsum @ $5 \mathrm{t} \mathrm{ha}^{-1}$ and @ 1.25 $\mathrm{t} \mathrm{ha}^{-1}$ was applied. The application of gypsum was found effective in removing soluble anions in soluble phase. The results are in conformity with findings of Patel and Singh (1991). The results of their findings showed that gypsum and press mud application were most effective in removing $\mathrm{CO}_{3}^{2-}$ and $\mathrm{HCO}_{3}^{-}$respectively. Similar findings with respect to gypsum application were also reported by Sharma et al., (2001). The excess chlorides increase the osmatic pressure of soil water and lower the water availability to plants. Some plants are sensitive to chloride and develop leaf burn symptoms when chloride concentration reaches about $0.5 \%$.In the present study noticed that chlorides significantly reduced in treatment $\mathrm{T}_{4}$ (1.06 me $\left.\mathrm{L}^{-1}\right)$ where we have applied farm yard manure@5 t ha ${ }^{-1}$ and gypsum @ $1.25 \mathrm{t} \mathrm{ha}^{-1}$. The next considerable reduction was see in the treatment $\mathrm{T}_{3}$ (1.21 me $\left.\mathrm{L}^{-1}\right)$ where gypsum @ 2.5 $\mathrm{t} \mathrm{ha}^{-1}$ was applied. With considering these reduction organic and in organic amendments are working very effectively in reducing soluble chlorides concentration. The Sulphates of saturation paste extract was influenced by various treatments. The significantly highest reduction was noticed in $\mathrm{T}_{4}\left(3.18 \mathrm{me} \mathrm{L}^{-1}\right.$.) The reduction in gypsum and farm yard manure amended furrow might be due to fast reclamation of gypsum as against organic amendments. Similar findings were also reported by Kharche et al., (2010) (Table 4).

\section{Available NPK}

Incorporation of gypsum and farm yard manure were enhanced the availability if nitrogen phosphorus and potassium. These might be happened due to farm yard manure and gypsum which is useful for soil reclamation. Higher value $198.30 \mathrm{~kg} \mathrm{ha}^{-1}$ of available nitrogen found in $\mathrm{t}_{4}$ where farm yard manure and gypsum were applied in integrated manner. In $\mathrm{T}_{3}$ also considerable improvement was seen when gypsum applied @ $2.5 \mathrm{t} \mathrm{ha}^{-1}$. Whereas in treatments $T_{1}$ and $T_{2}$. Improvement was comparatively less. These results are resembles with the findings of Vipin Kumar and Singh, (2010). Application of gypsum and FYM along with $100 \%$ NPK significantly enhanced available nitrogen content of soil over $100 \%$ NPK alone. The maximum value of phosphorus have been found in the $T_{4}\left(24.50 \mathrm{kgha}^{-1}\right)$ in which treatment gypsum and farm yard manure were collaborated. Slight improvement was noted in treatments $T_{2}$ and $T_{3}$. The lowest values were noted in treatment $T_{1}\left(19.28 \mathrm{kgha}^{-1}\right)$ where only $\mathrm{BBF}$ was practiced. These results are closely connected with the findings of Maurya et al., (2009) stated that the increase in available phosphorus status is due to use of organic amendments, being direct source of phosphorus. The effect of various treatments on available potassiumwas found to be significantly highest in $\mathrm{T}_{3}\left(346.12 \mathrm{~kg} \mathrm{ha}^{-1}\right)$ observed with gypsum application @ 2.5 tha $^{-1}$. Similar findings are reported by Chhabra,(2002). He stated thatthe application of gypsum@2.5 t ha ${ }^{-1}$ significantly enhanced the available potassium status of soil. Addition of gypsum brought about remarkable improvement in the physical and chemical properties of soil. These findings were in conformity with Yaduvanshi and Sharma (2007) (Table 5).

\section{Soybean yield}

In respect yield of soybean as influenced by various treatments. The highest soybean yield (14.03 $\mathrm{q} \mathrm{ha}^{-1}$ ) was obtained with the application of gypsum @1.25 tha ${ }^{-1}+$ farm yard manure @ 5 $\mathrm{t} \mathrm{ha}^{-1}$ on broad bed furrow system. Similarly considerable amount of yield was noticed in treatments where farm yard manure @ 5 tha $^{-1}$ and gypsum 2.5 tha $^{-1}$.were added separately. Similar enhancement observed in both cases grain and straw in same treatments. From the results of present investigation it becomes apparent that although gypsum is widely used as amendment for sodic soil on farm available organic amendments can be a better option for improving soil health as well as crop productivity. In view of the problems of availability of gypsum, the farm yard manure can serve as potential alternative for reclamation of calcareous sodic soil. The results 
are in conformity with the findings of Kumar et al., (2011) (Table 6).

In conclusion when considering improper drainage and salinity are the main constraints in Purna valley to mitigate these two barriers to obtain good yields in our experiment we imposed broad bed furrow and soil amendments. After determining the soil status before and after harvesting and comparing yields between with amendments and without amendments we came to know very clearly how our treatments were shown their potentialities in soil amelioration and soybean yield in salt affected soils of purna valley vidarbha. Combined utilisation of land configuration technique and soil amendments worked mutually when sodium is replaced by other cation, preferably calcium sodium was easily by drainage water which is facilitated by BBF. In other hand these BBF works as in situ soil moisture conservator and it provides congenial environments for the more root nodulation. Likewise we are concluding very confidently our treatments had played vital role in improving soil health especially with organic amendments and in soil reclamation as well as more yields of soybean in salt affected soils of purna valley in vidarbha.

\section{References}

Anonymous, 2010. Soil resource management for sustainable soil health and food security state level seminar held at a Dr. P.D.K.V, Akola, 2-3 Jan. pp 138-144.

Bharambe, P.R., D.K. Shelke, G.S. Jadhav, V.G.Vaishnava and S.R. Oza. 2001. Management of salt affected Vertisols with sub-suface drainage and crop residue incorporation under soybeanwheat cropping system. J. Indian Soc. Soil Sci. 49 (1):24-29.

Chhabra, R. (1996). Soil Salinity and Water Quality. Oxford and IBH Publishing Co. PVT. LTD., New Delhi, India, 284p.

Choudhary, O.P., B.S. Ghuman, Bijay Singh, N. Thuy and R.J. Buresh. 2011. Effect of long term use of sodic irrigation, amendments and crop residues on soil properties and crop yields in rice-wheat cropping system in a calcareous soil. Field Crop Research 121:363-372.

Dubey,S.K. and R.C. Mondal 1994. Effect of amendments and saline irrigation water on soil properties and yield of rice and wheat in a highly sodic soil. J. Agricultural Sci. Cambridge 122:351357.

Gupta, R. K., O.P Sharma and S.K. Dubey (1988): Effect of dose and frequency of gypsum application on properties of sodic soil and on performance of rice (Oryzasativa) and bread wheat (Triticum aestivum) Indian J. Agril.Sci.58 (6) 449-53.

Hanway, J.J. and H. Heidel, 1952.Soil Analysis Methods, as used in Iowa State.College Soil Testing Laboratory, Iowa, Agriculture. 57: 1-31.

Kaur, J., O.P. Choudhary and B. Singh. 2008. Microbial biomass carbon ans some soil properties as influenced by long term sodic water irrigation, gypsum and organic amendments. Aust. J. of Soil Res. 46:141-151.

Kharche, V.K., S.R. Patil, S.V. Belur and N.S. Ghogare. 2010. Integrated use of gypsum, spent-wash press-mud compost and bio-inoculants for reclamation od sodic swell shrink soils of Maharashtra. J. of Soil Salinity and Water Quality 2(2), pp- 110-115.

Kumar, A.B.M., Gowda, N.C.N., Shetty, G.R. and Karthik, M.N. 2011. Effect of organic manures and inorganic fertilizers on available NPK, microbial density of the soil and nutrient uptake of brinjal. Research Journal of Agricultural Sciences 2(2): 304-07.

Maurya, B.R., H. Ram and S.S. Prasad. 2009. Impact of soil amendments on properties of the salt affected rice soil. J. Indian Soc. Soil Sci. 57 (3):385-388.

More,S.D., G.U. Malewar and K.R. Pawar.(1987): MarathwadyatilKsharYuktaAniChopanJminivarilUpayYojana 
(in Marathi) Bull.1, Agril. Chemistry and Soil Sci. Dept., MAU, Parbhani (M.S.): PP 14-18.

Murtaza, G., M.N.Tahir, A. Ghafoor and M. Qadir. 2009. Calcium losses from gypsum and farm yard manure treated saline sodic soil during reclamation. International J. of Agric. and Bio. 15608530/99/01-1/2-019-022.

Padole, V.R., R.K. Chakolkar and P.W. Deshmukh, 1998. Characterization of salt affected Vertisols of Vidarbha region of Maharashtra. PKV Res. J. 22:26-34

Panse, V.G. and P.V. Sukhatme. 1971. Statistical Methods for Agricultural Workers. ICAR, New Delhi, pp- 110 113.

Patel, K.P., and Singh, 1991.A comparative study on the effect of gypsum, pressmud and pyrites on leachate composition, soil properties and yield of rice and wheat on a sodic soil.J. Indian Soc.Soil Sci. 39:154-159.

Ram Harisingh G, Aggrawa N, and Kaur.J 2011. Soybean growth, productivity and water use under different sowing methods and seeding rates in Punjab.Indian journal of Agronomy 56(4)377-80.

Richards, L.A. (1954). Diagnosis and Improvement of Saline and Alkaline Soils.United States Salinity Laboratory Staff.Agricultural Handbook No 60.United States Department of Agriculture, 160p.

Rochester, I.,JM.B.Peoples, N.R. Hulugalie, R.R. Gault and G.AConstabl., 2001.
Using legumes to enhance nitrogen fertility and improve soil condition in cotton cropping systems. Field Crops Res., 70(1):27-4.

Sharma, R.C., A.K. Mandal, R. Singh and Y.P. Singh. 2011. Characteristics and use potential of sodic and associatrd soils in CSSRI experimental farm, Lucknow, Uttar Pradesh. J. Indian Soc. Soil Sci. 59 (4):381-387

Shivakant and Rajkumar (1992): Effect of gypsum, pyrite, pressmud and FYM on soil properties and yield of rice (Oryzasativa). Indian J. of agril. Sci.62 (3): 191-5.

Singh D.V,vyas A K, Gupta G K, Ramteke R and Khan I R 1980. Tractor drawn Broad bed furrow seed drill machine to over come moisture stress for soybean.(glycine max) in Vertisols.Indian journal of agriculture sciences 81:941-4.

Vipin Kumar and A.P. Singh.2010.Long term effect of green manuring and farm yard manure on yield and soil fertility status in rice-wheat cropping system. J. Indian Soc. Soil Sci. 58 (4):409-412.

Watanabe, F.S. and S.R. Olsen, 1965. Test of ascorbic acid method for determining phosphorus in water and sodium bicarbonate extracts of soils. Proc. Soil Sci. Soc. Am., 29: 677-678.

Yaduvanshi, N.P.S. and D.R. Sharma. 2007. Use of wheat residue and manures to enhance nutrient availability and ricewheat yields in sodic soil under sodic water irrigation. J. Indian Soc. Soil Sci. 55 (3):330-334.

\section{How to cite this article:}

Ravinder, J., Tupaki Lokya, N.M. Konde and Princy Thakur. 2017. Potentiality of BBF and Soil Amendments in Degraded Purnavalley Soils Reclamation and Soybean Yield. Int.J.Curr.Microbiol.App.Sci. 6(6): 2540-2548. doi: https://doi.org/10.20546/ijcmas.2017.606.302 